\title{
Orthodontics-Awareness Amongst Medical Students
}

\author{
Türkan SEZEN ERHAMZA' ${ }^{1}$, Kübra ARSLAN ÇARPAR' \\ ${ }^{1}$ Assistant Proffessor, Department of Orthodontics, \\ Faculty of Dentistry, Kirikkale University, Kirikkale, Turkey
}

Corresponding author: Asst. Prof. Türkan SEZEN ERHAMZA, Email: dt.turkansezen@gmail.com

\section{ABSTRACT}

Introduction: The study aimed to evaluate the knowledge and awareness of orthodontics, a specialty of dentistry, amongst Medical Students.

Materials and Method: A sample of 550 students ( 279 female, 226 male aged between 18 and 36 years) were attented. Of the subjects, $58.6 \%(n=296)$ were preclinical students, while $41.4 \%(n=209)$ were clinical students. The students were informed about the questionnaire and asked to fill in the questionnaire forms. For the comparison of data between groups (gender, level of education), the chi-square test was used. A chi-square test was used for statistical evaluation and the $p$-value $<0.05$ was considered statistically significant.

Result: 385 students $(76.2 \%)$ had heard the term orthodontics although $41.2 \%$ of the subjects knew that orthodontics was concerned with malocclusions and their treatment. The question about treatment procedures was answered as scaling by $35.8 \%$, tooth polishing by $40 \%$, tooth aligning by $89.9 \%$ of the students. The percentage of knowing orthodontics to be related to tooth aligning showed a significant difference between female and male $(p=0.006)$, and preclinical and clinical students ( $p=0.033$ ). Of the participants, $42.8 \%$ thought that dentures, $83 \%$ brackets, $78.8 \%$ of removable appliances were used by orthodontists.

Conclusion: Our results have shown that medical students should have more information about orthodontics, a specialty of dentistry.

KEYWORDS: Awareness, Knowledge, Medical Student, Orthodontics.

\section{INTRODUCTION}

According to the World Health Organization, malocclusion is defined as a dental and / or skeletal anomaly causing aesthetic impairment or impaired function, which may be an obstacle for the physical and emotional well-being of the patients, requiring orthodontic treatment. ${ }^{1}$ Although malocclusion is not life-threatening, it is considered as an important public health problem. One of the most important effects of malocclusion is psychosocial effects caused by the deterioration of the tooth and facial aesthetics of the individual. Decreased dental aesthetics can affect the quality of life, self-esteem, and self-confidence. ${ }^{2}$

Individuals with orthodontic problems have been stated to hide their teeth while laughing, to close their mouths with hands while talking, not to want their teeth to appear in the photographs, and these behaviors, stemming from the appearance of teeth, are more common in children than adults. ${ }^{3}$

The request to receive orthodontic treatment mostly arise from aesthetic demand. ${ }^{4}$ Causes such as biting and mastication, temporomandibular joint disorders, and headache are among other reasons stated for orthodontic treatment. ${ }^{5}$ In a study, patients also expressed reasons such as pain or tooth discoloration for orthodontic treatment. This situation implies the unconsciousness and the lack of education about orthodontic treatment. ${ }^{6}$ Medical doctors are the first to apply for health-related events. Throughout the country, medical practitioners are known to be applied more than dentists, and in some rural areas, oral and dental health training is given by medical practitioners. ${ }^{7,8}$ Despite all these reasons, very few patients who apply to the orthodontic clinic are directed by the medical doctor. 
Also, adequate training on oral and dental health is known not to be available within the scope of the education of the medical school. ${ }^{9-11}$ This study aimed to evaluate the levels of orthodontics knowledge and awareness of medical faculty students, future medical doctors.

\section{MATERIALS AND METHOD}

Our study is a cross-sectional descriptive study with a population consisted of students studying in the Medical Faculty of X University in 2018-2019. Ethics committee approval was obtained from $X$ University Non-Invasive Research Ethics Committee (Decision number. 2019.03.11). Additionally, approval and voluntary informed consent forms were collected from the diaconate of the medical faculty and all subjects participated in the study, respectively.

A total of 550 students ( 279 female, 226 male) with ages between 18 and 36 years from Kırıkkale University, Medical Faculty was attended in the present study. Of the subjects, $58.6 \%(n=296)$ were preclinical students, while $41.4 \%(n=209)$ were clinical students. The students were informed about the questionnaire and asked to fill in the questionnaire forms.

The questionnaire form consisted of eight questions. The first three questions were related to the definition of oral health and orthodontics. The third and fourth questions, about the treatments carried out by orthodontists, were composed of five and three parts, respectively. The sixth question consisted of five parts related to daily functions affected by orthodontic malocclusion. The last two questions were about patient orientation. (Table 1)

SPSS software (version 20; IBM, Armonk, NY) was used for statistical analyses. The Shapiro-Wilk test was used to analyze the data in terms of distribution. Percentage values were presented for discrete data. For the comparison of groups (gender, level of education), the chi-square test was used. Statistical significance was considered as the $p$-value $<0.05$.

\section{RESULTS}

In the posthoc power analysis related to the sample size using the G Power-3.1.9.2 program, the effect size was found to be 0.138 , with a $95 \%$ confidence level. The power of the study with a sample size of 505 was approximately 0.71 . In the study, a total of 505 students (279 female, 226 male) were enrolled with a mean age of $21,18 \pm 2,33$. Gender and level of education distribution were presented in Table 2. Of the subjects, $58.6 \%(n=$ 296) were preclinical students, while $41.4 \%(n=209)$ were clinical students. Of the participants, $54.7 \%$ had obtained oral dental health information from dentists. No difference was found between female and male $(p=0.689)$ or preclinical and clinical students $(p=0.459)$ in terms of the information source about oral and dental health. (Table 1)

Although 385 people (76.2\%) have heard the term orthodontics, $41.2 \%$ of the participants knew that orthodontics deals with malocclusions relevant treatment. There was no significant difference between gender groups or between the preclinical and clinical students in terms of knowing the term orthodontics ( $p>0.05$ ). A statistically significant difference was identified between preclinical and clinical student groups for knowing orthodontics is concerned with malocclusions. $(p=0.000)$ (Table 1) When the classes were evaluated separately, the rate of those who heard the term orthodontics increased as the class increased, and this relation was found to be statistically significant $(p=0.006)$. Whereas $13.9 \%$ of the first-year students knew orthodontics was interested in malocclusions, the relevant percentage increased as the education year increased, reaching $50.6 \%$ for the fifth-year and $53.4 \%$ for the sixth-year students. This difference was found to be significant $(p=0,000)$.

$27.1 \%$ of the students who participated in the questionnaire regarding the treatment procedures in the field of orthodontics gave the answers filling and tooth extraction, $35.8 \%$ scaling, $40 \%$ tooth polishing, and $89.9 \%$ tooth aligning. Knowing that orthodontics deals with tooth aligning showed a significant difference between female and male $(p=0.006)$ and between preclinical and clinical students $(p=0.033)$. The preclinical students thought that orthodontists performed scaling at a high rate compared to clinical students. $(P=0.001)$

Of the first-year students, $54.4 \%$ and of the sixth-year students $17.2 \%$ stated that orthodontists scale the tooth. The higher the education year the lower that percentage, that is the majority of the classes stated orthodontists did not scale the tooth beginning from the second-year. That relation was found to be statistically significant. $(P=0.000)$.

Whereas $79.7 \%$ of the first-year students knew orthodontists provided tooth aligning, the related percentage was $96.6 \%$ for the sixth-year students. This 
rate increased with the education year. This difference between groups was found to be statistically significant. $(P=0.025)$

Of the participants, $42.8 \%$ stated dentures, $83 \%$ brackets, $78.8 \%$ of removable appliances were used by orthodontists. This information did not differ between female and male, or between preclinical and clinical students. $(p>0.05)($ Table 1$)$

The answers given by the participants to the question of what functions malocclusions affect in daily life can be seen in Table 1. Female students, compared to male students, thought that speaking was more affected by a malocclusion. ( $p=0.005)$ Preclinical students, compared to clinical students, stated that appearance $(p=0.002)$, quality of life $(p=0.031)$, self-esteem $(p=$ $0.009)$ and mastication $(p=0.005)$ were more affected by malocclusion. (Table 1 )

The answer given by medical students to the question of whether they will refer patients to the orthodontist or the medical doctor is shown in Table 1. There was no significant difference between the genders or between the preclinical and clinic students. $(p>0.05)$

Table 1. Distrubition and differences of respondents' replies according to genders and level of education, respectively.

\begin{tabular}{|c|c|c|c|c|c|c|c|}
\hline \multirow[b]{2}{*}{ Survey Questions } & \multirow{2}{*}{\begin{tabular}{|l|} 
All of samples \\
$n(\%)$
\end{tabular}} & \multicolumn{2}{|c|}{ Gender } & \multirow[b]{2}{*}{$\mathbf{p}$} & \multicolumn{2}{|c|}{ Unend laffeatluactition } & \multirow[b]{2}{*}{ p } \\
\hline & & Female $\mathrm{n}(\%)$ & Male $\mathrm{n}(\%)$ & & Preclinical $n(\%)$ & Clinical n(\%) & \\
\hline $\begin{array}{l}\text { 1. Where have you received } \\
\text { source of information on } \\
\text { oral health prior to study? }\end{array}$ & & & & 0,689 & & & 0,459 \\
\hline A. Dentist & $276(54.7 \%)$ & $148(53 \%)$ & $128(56.6 \%)$ & & $167(56,4 \%)$ & $109(52,2 \%)$ & \\
\hline B. Doctor/Nurse & $38(7.5 \%)$ & $22(7.9 \%)$ & $16(7.1 \%)$ & & $24(8,1 \%)$ & $14(6,7 \%)$ & \\
\hline C. Lecturers/Seminars & $79(15.6 \%)$ & $46(16.5 \%)$ & $33(14.6 \%)$ & & $43(14,5 \%)$ & $36(17,2 \%)$ & \\
\hline D. Magazines/Books & $28(5.5 \%)$ & $15(5.4 \%)$ & $13(5.8 \%)$ & & $17(5,7 \%)$ & $11(5,3 \%)$ & \\
\hline E. Radio/Tv & $31(6.1 \%)$ & $21(7.5 \%)$ & $10(4.4 \%)$ & & $20(6,8 \%)$ & $11(5,3 \%)$ & \\
\hline F. Others & $53(10.5 \%)$ & $27(9.7 \%)$ & $26(11.5 \%)$ & & $25(8.4 \%)$ & $28(13.4 \%)$ & \\
\hline $\begin{array}{l}\text { 2. Have you known the } \\
\text { term orthodontics? }\end{array}$ & & & & 0,785 & & & 0,437 \\
\hline A. Yes & $385(76.2 \%)$ & $214(76.7 \%)$ & $171(75.5 \%)$ & & $222(75 \%)$ & $163(78 \%)$ & \\
\hline F. No & $120(23.8 \%)$ & $65(23.3 \%)$ & $55(24.3 \%)$ & & $74(25 \%)$ & 456(20128d) & \\
\hline $\begin{array}{l}\text { 3. Have you known that } \\
\text { orthodontics involves } \\
\text { malocclusion and its } \\
\text { management? }\end{array}$ & & & & 0,176 & & & 0,000 \\
\hline A. Yes & $208(41.2 \%)$ & $115(41.2 \%)$ & $93(41.2 \%)$ & & $103(34,8 \%)$ & $105(50,2 \%)$ & \\
\hline E. No & $297(58.8 \%)$ & $164(58.8 \%)$ & $133(58.8 \%)$ & & $193(65,2 \%)$ & $11004((49998 \% 9))$ & \\
\hline $\begin{array}{l}\text { 4a. Would the filling be } \\
\text { made by orthodontists? }\end{array}$ & & & & 0.588 & & & 0,173 \\
\hline A. Yes & $137(27.1 \%)$ & $73(26.2 \%)$ & $64(28.3 \%)$ & & $87(29.4 \%)$ & $50(23.9 \%)$ & \\
\hline E. No & $368(72.9 \%)$ & $206(73.8 \%)$ & $162(71.7 \%)$ & & 209 (70.6\%) & $159(76,1 \%)$ & \\
\hline $\begin{array}{l}\text { 4b. Would the extracting } \\
\text { teeth be carried out by } \\
\text { orthodontists? }\end{array}$ & & & & 0,890 & & & 0,247 \\
\hline A. Yes & $137(27.1 \%)$ & 75 (26.9\%) & 62 (27.4\%) & & $86(29,1 \%)$ & $51(24,4 \%)$ & \\
\hline E. No & 368 (72.9\%) & $204(73.1 \%)$ & $164(72.6 \%)$ & & $210(70,9 \%)$ & 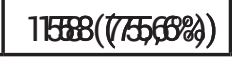 & \\
\hline
\end{tabular}




\begin{tabular}{|c|c|c|c|c|c|c|c|}
\hline \multirow[b]{2}{*}{ Survey Questions } & \multirow{2}{*}{\begin{tabular}{|l|} 
All of samples \\
$n(\%)$
\end{tabular}} & \multicolumn{2}{|c|}{ Gender } & \multirow[b]{2}{*}{ p } & \multicolumn{2}{|c|}{ Lend loffeathucation } & \multirow[b]{2}{*}{$\mathbf{p}$} \\
\hline & & Female n(\%) & Male n(\%) & & Preclinical $n(\%)$ & Clinical n(\%) & \\
\hline $\begin{array}{l}\text { 4c. Would the scaling be } \\
\text { carried out by orthodontists? }\end{array}$ & & & & 0,093 & & & 0,001 \\
\hline A. Yes & $181(35.8 \%)$ & $91(32.6 \%)$ & $90(39.8 \%)$ & & $123(41.6 \%)$ & $58(27,8 \%)$ & \\
\hline E. No & $324(64.2 \%)$ & $188(67.4 \%)$ & $136(60.2 \%)$ & & $173(58.4 \%)$ & 11581 (प12212\%) & \\
\hline $\begin{array}{l}4 \mathrm{~d} \text {. Would the polishing } \\
\text { teeth be carried out by } \\
\text { orthodontists? }\end{array}$ & & & & 0,116 & & & 0,077 \\
\hline A. Yes & $202(40 \%)$ & $103(36.9 \%)$ & $99(43.8 \%)$ & & $128(43.2 \%)$ & $74(35.4 \%)$ & \\
\hline E. No & $303(60 \%)$ & $176(63.1 \%)$ & $127(56.2 \%)$ & & $168(56.8 \%)$ & 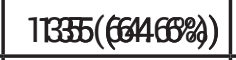 & \\
\hline $\begin{array}{l}\text { 4e. Would the aligning teeth be } \\
\text { caried out by orthodontists? }\end{array}$ & & & & 0,006 & & & 0,033 \\
\hline A. Yes & $454(89.9 \%)$ & $260(93.2 \%)$ & $194(85.8 \%)$ & & $259(87.5 \%)$ & $195(93.3 \%)$ & \\
\hline E. No & $51(10.1 \%)$ & $19(6.8 \%)$ & $32(14.2 \%)$ & & $37(12.5 \%)$ & $174(6677 \% 8)$ & \\
\hline $\begin{array}{l}\text { 5a. Would the } \\
\text { dentures be applied by } \\
\text { orthodontists? }\end{array}$ & & & & 0.809 & & & 0.799 \\
\hline F. No & $216(42.8 \%)$ & $118(42.3 \%)$ & $98(43.4 \%)$ & & $128(43.2 \%)$ & $88(42.1 \%)$ & \\
\hline F. No & $289(57.2 \%)$ & $161(57.7 \%)$ & $128(56.6 \%)$ & & $168(56.8 \%)$ & $121(57.9 \%)$ & \\
\hline $\begin{array}{l}\text { 5b. Would the braces be } \\
\text { applied by orthodontists? }\end{array}$ & & & & 0,563 & & & 0.853 \\
\hline A. Yes & $421(83.4 \%)$ & $235(84.2 \%)$ & $186(82.3 \%)$ & & $246(83.1 \%)$ & $175(83.7 \%)$ & \\
\hline H. No & $84(16.6 \%)$ & $44(15.8 \%)$ & $40(17.7 \%)$ & & $50(16.9 \%)$ & $34(16.3 \%)$ & \\
\hline $\begin{array}{l}\text { 5c. Would the removable } \\
\text { appliances be applied by } \\
\text { orthodontists? }\end{array}$ & & & & 0,643 & & & 0,874 \\
\hline A. Yes & $398(78.8 \%)$ & $222(79.6 \%)$ & $176(77.9 \%)$ & & $234(79.1 \%)$ & $164(78.5 \%)$ & \\
\hline H. No & $107(21.2 \%)$ & $57(20.4 \%)$ & $50(21.1 \%)$ & & $62(20.9 \%)$ & $45(21.5 \%)$ & \\
\hline $\begin{array}{l}\text { 6a. Would appearance be } \\
\text { affected by malocclusion? }\end{array}$ & & & & 0,225 & & & 0,002 \\
\hline A. Yes & $460(91.1 \%)$ & $258(92.5 \%)$ & $202(89.4 \%)$ & & $260(87.8 \%)$ & $200(95.7 \%)$ & \\
\hline H. No & $45(8.9 \%)$ & $21(7.5 \%)$ & $24(10.6 \%)$ & & 36 (12.2\%) & $9(4.3 \%)$ & \\
\hline $\begin{array}{l}\text { 6b. Would speech be } \\
\text { affected by malocclusion? }\end{array}$ & & & & 0,005 & & & 0.075 \\
\hline A. Yes & $460(91.1 \%)$ & $263(94.3 \%)$ & $197(87.2 \%)$ & & 264 (89.2\%) & $196(93.8 \%)$ & \\
\hline B. No & $45(8.9 \%)$ & $16(5.7 \%)$ & $29(12.8 \%)$ & & $32(10.8 \%)$ & $13(\% 6.2)$ & \\
\hline $\begin{array}{l}6 \mathrm{c} \text {. Would quality of life be } \\
\text { affected by malocclusion? }\end{array}$ & & & & 0,094 & & & 0,031 \\
\hline A. Yes & $418(82.8 \%)$ & $238(85.3 \%)$ & $180(79.6 \%)$ & & $236(79.7 \%)$ & $182(87.1 \%)$ & \\
\hline E. No & $87(17.2 \%)$ & $41(14.7 \%)$ & $46(20.4 \%)$ & & $60(20.3 \%)$ & $27(12.9 \%)$ & \\
\hline
\end{tabular}




\begin{tabular}{|c|c|c|c|c|c|c|c|}
\hline \multirow[b]{2}{*}{ Survey Questions } & \multirow{2}{*}{$\begin{array}{l}\text { All of samples } \\
n(\%)\end{array}$} & \multicolumn{2}{|c|}{ Gender } & \multirow[b]{2}{*}{ p } & \multicolumn{2}{|c|}{ Leovilaffeathocattion } & \multirow[b]{2}{*}{ p } \\
\hline & & Female $n(\%)$ & Male n(\%) & & Preclinical n(\%) & Clinical n(\%) & \\
\hline $\begin{array}{l}6 \mathrm{~d} \text {. Would self-esteem be } \\
\text { affected by malocclusion? }\end{array}$ & & & & 0,304 & & & 0,009 \\
\hline A. Yes & $410(81.2 \%)$ & $231(82.8 \%)$ & $179(79.2 \%)$ & & $229(77.4 \%)$ & $181(86.6 \%)$ & \\
\hline E. No & $95(18.8 \%)$ & $48(17.2 \%)$ & $47(20.8 \%)$ & & $67(22.6 \%)$ & $28(13.4 \%)$ & \\
\hline $\begin{array}{l}\text { 6e. Would mastication be } \\
\text { affected by malocclusion? }\end{array}$ & & & & 0,083 & & & 0.005 \\
\hline A. Yes & $475(94,1 \%)$ & $267(95.7 \%)$ & $208(92 \%)$ & & 271 (91.6\%) & 204 (97.6\%) & \\
\hline E. No & $30(5.9 \%)$ & $12(4.3 \%)$ & $18(8 \%)$ & & $25(8.4 \%)$ & $5(2.4 \%)$ & \\
\hline $\begin{array}{l}\text { 7. Should doctors refer } \\
\text { patients to orthodontists? }\end{array}$ & & & & 0,444 & & & 0,932 \\
\hline A. Yes & $438(86.7 \%)$ & $244(87.5 \%)$ & $194(85.8 \%)$ & & $258(87.2 \%)$ & $180(286.1 \%)$ & \\
\hline B. Undecided & $56(11.1 \%)$ & $31(11.1 \%)$ & $25(11.1 \%)$ & & $32(10.8 \%)$ & $24(11.5 \%)$ & \\
\hline C. No & $11(2.2 \%)$ & $4(1.4 \%)$ & $7(3.1 \%)$ & & $6(2 \%)$ & $5(2.4 \%)$ & \\
\hline $\begin{array}{l}\text { 8. Should doctors refer } \\
\text { patients to medical } \\
\text { doctors? }\end{array}$ & & & & 0,677 & & & 0,321 \\
\hline A. Yes & $429(85 \%)$ & $234(83.9 \%)$ & $195(86.3 \%)$ & & $253(85.5 \%)$ & $176(84.2 \%)$ & \\
\hline B. Undecided & $61(12.1 \%)$ & $37(13.3 \%)$ & $24(10.6 \%)$ & & $37(12.5 \%)$ & $24(11.5 \%)$ & \\
\hline C. No & $15(3 \%)$ & $8(2.9 \%)$ & $7(3.1 \%)$ & & $6(2 \%)$ & $9(4.3 \%)$ & \\
\hline
\end{tabular}

Table 2. Distiribution of gender and level of education.

\begin{tabular}{|l|l|l|}
\hline & $n$ & $\%$ \\
\hline Gender & & \\
\hline Female & 279 & 55,2 \\
\hline Male & 226 & 44,8 \\
\hline Level of education & & \\
\hline 1 & 79 & 15,6 \\
\hline 2 & 102 & 20,2 \\
\hline 3 & 115 & 22,8 \\
\hline 4 & 74 & 14,7 \\
\hline 5 & 77 & 15,2 \\
\hline 6 & 58 & 11,5 \\
\hline Total & 505 & 100 \\
\hline
\end{tabular}

\section{DISCUSSION}

Medical doctors are the first to be applied to health problems. ${ }^{7,} 8$ Considering that there is a low level of awareness and lack of education about orthodontic treatment, ${ }^{6}$ and the fact that medical doctors are applied more frequently than dentists in our country ${ }^{8}$, it has been suggested that medical doctors should know about dentistry so that they can refer patients to dentists, and this study was decided to be conducted. This is the very first study evaluating the orthodontic awareness of medical students in our country. 
In a study conducted among 374 individuals aged 6 and over in Turkey, $69.3 \%$ of the patients stated that they demanded orthodontic treatment to have their teeth straightened, $9.9 \%$ to have a better aesthetic appearance, $5.3 \%$ to be able to eat better, $2 \%$ to correct their speech and $1.1 \%$ to have a better smile. In the same study, $60 \%$ of the patients stated that they knew about orthodontic treatment and $40 \%$ said they did not know what orthodontic treatment was. It was determined that $19.6 \%$ of the patients who had an idea about orthodontic treatment had a misunderstanding, while $7.6 \%$ had insufficient information. ${ }^{12}$

Recently, the importance given to aesthetic appearance and quality of life has been observed to become greater leading to an increased awareness of malocclusions and consequently a significant increase in orthodontic treatment demands. ${ }^{13,14}$ Due to the increase in demand for orthodontic treatment, orthodontics became known as a specialty of dentistry. ${ }^{9}$

Although most of the students stated that they heard about the orthodontics field in our study, it was revealed that the students had insufficient information about what orthodontists did. This result is similar to previous studies. ${ }^{9,15,16}$ Clinical students were found to have more knowledge than preclinical students. With the advancement of the class, the knowledge levels in the field of orthodontics have increased and the knowledge level of the first-year students has been observed to be quite incomplete compared to otheryear students. While a difference was found between female and male students in terms of familiarity with the term orthodontics ${ }^{17}$, Mendonca et al. ${ }^{15}$ did not find any difference supporting our study.

Most of the first-year medical students think that orthodontists do fillings, tooth extraction, polishing, tooth scaling as well as tooth aligning. The percentage of students who think orthodontists do filling, tooth extraction, polishing, or scaling has decreased beginning from second-year students. Additionally, filling and extraction responses were reported to have a ratio of $38.8 \%$ by Adegbite et al. ${ }^{9} 45.4 \%$ by Shahrani et al. ${ }^{17}$, approximately $35 \%$ by Newman et al. ${ }^{18}$, and $30 \%$ by Mendonca et al. ${ }^{15}$ among medical students. In our study, corresponding rates were found to be lower $(27 \%)$. The consideration that the aligning of the teeth is done by orthodontists shows a wide range between $27 \%$ and $81 \%$. Although the results showed that medical students do not have much knowledge about the procedures performed by orthodontists in our country, the level of knowledge and awareness was found to be higher than the countries where other studies were conducted.

Most of the participants knew about the appliances used by orthodontists. While $83.4 \%$ of the participants knew that orthodontists use brackets, fewer people $(78.8 \%)$ knew orthodontists use mobile appliances. That may stem from the fact that mobile appliances are not used in adult patients while brackets are. Although the fact that orthodontists use brackets is known at high percentages in several studies, corresponding value about mobile appliances varies between $39 \%-40 \% .17,18$ Orthodontic problems are usually ignored by healthcare professionals, as not being life-threatening or diseasecausing. However, malocclusions that disrupt facial aesthetics are known to affect psychosocial health, and improvement of oral function, dental and aesthetic appearance provides psychological well-being and increases the quality of life. ${ }^{9,19,20}$ Therefore, patients with malocclusion should be immediately referred to specialists. $^{9}$

In our study, the participants thought mastication, appearance, and speech would be affected the most from malocclusion. The rate of students who think the quality of life and self-esteem will be affected is lower. In a study, the number of people who applied to orthodontic treatment for aesthetic reasons was reported to be $80 \%{ }^{12}$ The high rate of thought that malocclusion will affect the appearance in the survey results supports this study.

In other countries, daily functions are thought to be affected by malocclusions at a ratio between $40 \%$ and $80 \% .^{9,18}$ In our study, clinical students, compared to preclinical students, thought that appearance, quality of life, self-esteem, and mastication would be more affected by malocclusion at a higher ratio. This finding might result from the awareness of candidates about oral and dental health, and their interaction with friends from the faculty of dentistry.

According to the data of the Ministry of Health of our country in 2018 , the number of physicians per hundred thousand citizens is 187 and the relevant number of dentists is 37 . When assessed according to the regions, the difference increases even more in some regions. Specialist dentists make up only $8.3 \%$ of dentists. As 
of $2018,19 \%$ of physicians work in the private sector, while $50 \%$ of dentists work in the private sector. Since the treatments in the private sector are not covered by the government, patients tend to go to public hospitals, university hospitals, or tend to delay their treatment. ${ }^{21}$ In areas where the number of dentists is inadequate or a dentist is absent, patients can apply to medical doctors. ${ }^{7,} 8$ Therefore, medical doctors have sufficient information on dental health is of great importance.

When studies on malocclusion prevalence in our country were examined, malocclusions were identified in $89.9 \%$ of children at an age of 14.6 years in Central Anatolia, in $29.4 \%$ of children at an age of 6-11 in Adana, and $29.2 \%$ in a study conducted for Ankara province. ${ }^{22-24}$ When detected malocclusions are not treated, they can transform into permanent dentition. Bad habits such as thumb sucking, mouth breathing when not intervened in the early period may cause skeletal problems, posterior cross-bite, severe asymmetries, and severe malocclusions. ${ }^{20}$ Thus, it is important to correct early dental disorders. At this stage, it is seen that the referral of medical doctors to orthodontists at an early age will give a chance to intervene before serious malocclusions occur.

In our study, the majority of the participants reported that in the presence of malocclusion, patients would refer to the orthodontist. Approximately $13 \%$ of medical students stated they thought they were undecided or negative in referral. It is thought that to increase the knowledge and awareness levels of the negative and unstable physician candidates, adding tutorial lessons containing information about oral and dental health specialties to medical education would be necessary.

Considering the limitations of our study and suggestions for future studies, the sample size would be increased. In this way, the power of the study would also increase. Moreover, the inclusion of more medical students from different universities from various regions of the country will be beneficial in terms of generalization. In our country, studies related to this subject have not been encountered. The requirement for such studies should be taken into consideration, as well as issues related to oral and dental health in medical education.

\section{CONCLUSION}

The results of our study suggest that medical students should have more information about orthodontics, one of the dentistry specialties. Medical students to have sufficient knowledge about the dentistry specialties of future medical students is of great importance, especially for the ability to treat patients without early malocclusions or aggravation. 


\section{REFERENCES}

1. Organization WH. Basic documents. Geneva. World Health Organization. 2014:1.

2. Işık F, Sayınsu K, Trakyalı G, Arun T. Hastanın psikolojik durumunun ya da kişilik özelliklerinin ortodontik tedavi başarısı üzerine etkileri. Türk Ortodonti Derg. 2004;17(3):347-53.

3. Chen M, Wang D-W, Wu L-P. Fixed orthodontic appliance therapy and its impact on oral health-related quality of life in Chinese patients. The Angle Orthodontist. 2010;80(1):49-53.

4. Mandall N, Wright J, Conboy F, O'Brien K. The relationship between normative orthodontic treatment need and measures of consumer perception. Community Dental Health. 2001;18(1):3.

5. Wędrychowska-Szulc B, Syryńska M. Patient and parent motivation for orthodontic treatment-a questionnaire study. The European Journal of Orthodontics. 2010;32(4):447-52.

6. El-Momani BR, Tarawneh AM. Why Jordanians seek orthodontic treatment? Demand and real need. Journal of the Royal Medical Services. 2014;102(1003):1-5.

7. Al-Omiri MK, Barghout NH, Shaweesh Al, Malkawi Z. Level of education and gender-specific self-reported oral health behavior among dental students. Oral health \& preventive dentistry. 2012;10(1).

8. Ergüven SS, Kılınç $Y$, Delilbaşı $E$, Işık B. Bir diş hekimliği fakültesi ağız, diş ve çene cerrahisi kliniğine başvuran hastaların dental kaygı düzeylerinin değerlendirilmesi. Acta Odontologica Turcica. 2015;32(1):7-11.

9. Adegbite $\mathrm{K}$, Ogunbanjo B, Ajisafe $\mathrm{O}$, Adeniyi A. Knowledge of orthodontics as a dental specialty: A preliminary survey among LASUCOM students. Annals of medical and health sciences research. 2012;2(1):14-8.

10. Ramirez JH, Arce R, Contreras A. Why must physicians know about oral diseases? Teaching and learning in medicine. 2010;22(2):148-55.

11. Zhang S, Lo EC, Chu C-H. Attitude and awareness of medical and dental students towards collaboration between medical and dental practice in Hong Kong. BMC oral health. 2015;15(1):53.

12. Aksoy A. Illk pilot ağız diş hastalıkları hastanesi ortodonti bölümüne başvuran hastaların sosyo-ekonomik profili. SDÜ Tıp Fakültesi Dergisi. 2005;12(2):38-45.

13. Abu Alhaija E, Al-Wahadni A. Relationship between tooth irregularity and periodontal disease in children with regular dental visits Journal of Clinical Pediatric Dentistry. 2006;30(4):296-8.

14. Khanehmasjedi M, Bassir L, Haghighizade MH. Evaluation of orthodontic treatment needs using the dental aesthetic index in Iranian students. Iranian Red Crescent Medical Journal. 2013;15(10).

15. Mendonca M, D'cruz AM, Soans CR, Patla M, Mohammed A, Shetty P, et al. Medical Students' Awareness of Orthodontics-A Comparative Ouestionnaire Survey Study Between The Students of a Medical College Atached With A Dental College Attached With A Dental College and A Stand-Alone Medical College Journal of Evolution of Medical and Dental Sciences. 2018;7(32):3569-77.

16. Sharma R, Kumar S, Singla A, Kumar D, Chowdhary S. Knowledge, attitude and practices of pediatricians regarding malocclusion in Haryana, India. Journal of Indian Association of Public Health Dentistry. 2016;14(2):197.

17. Al Shahrani I, Kandyala R. Medical students' awareness of orthodontics: a cross sectional study in King Khalid University, Abha, Saudi Arabia. Archives of Orofacial Science. 2014;9(1).

18. Newman-Nartey M, Osei-Tutu K, Ogunbanjo B, Adegbite K. Awareness and Knowledge of Orthodontics as a Specialty of Dentistry amongst students of the University of Ghana Medical School. West African Journal of Orthodontics. 2013;2(2):30-4.

19. Onyeaso C, Sanu O. Psychosocial implications of malocclusion among 12-18 year old secondary school children in Ibadan, Nigeria. Odonto-stomatologie tropicale= Tropical dental journal. 2005;28(109):39.

20. ÖZ E, Küçükeşmen Ç. Çocuklarda Maloklüzyon ve Ortodontik Tedavi İhtiyacı. Turkiye Klinikleri Dishekimligi Bilimleri Dergisi. 2019;25(2).

21. Bilgi TSBS, Müdürlüğü G. Sağlık İstatistikleri Yıllığı 2018 Haber Bülteni. 2019. URL: https://dosyamerkez saglik gov tr/Eklenti/27344, saglik-istatistikleri-yilligi-2017-haber-bultenipdf pdf.

22. Gelgör IE, Karaman IA, Ercan E. Prevalence of malocclusion among adolescents in central anatolia. European journal of dentistry. 2007;1(03):125-31.

23. Öztunç $H$, Haytaç $M C$, Özmeriç N, Uzel İ. Adana ilinde 6-11 yaş grubu çocukların ağız-diş sağlığı durumlarının değerlendirilmesi. Gazi Üniversitesi Diş Hekimliği Fakültesi Dergisi. 2000;17(2):1-6.

24. Altun C, Güven G, Başak F, Akbulut E. Evaluation of children in the age group of 6 to 11 with respect to oral-dental health. Gulhane Med J. 2005;47:114-8 